\title{
Mission, migration and human development: A new approach
}

\begin{abstract}
Author:
Akinyemi O. Alawode ${ }^{1}$

Affiliation:

${ }^{1}$ Faculty of Human and Social Sciences, Department of Theology, North-West University, Mafikeng Campus, South Africa

Correspondence to:

Akinyemi O. Alawode

Email:

akinalawode@gmail.com

Postal address:

Fountain View 401, Willow

Road 71, Muckleneuk 0002,

South Africa

Dates:

Received: 01 Oct. 2014

Accepted: 28 Apr. 2015

Published: 03 July 2015

How to cite this article:

Alawode, A.O., 2015,

'Mission, migration and

human development: A new

approach', In die Skriflig

49(1), Art. \#1888, 7 pages.

http://dx.doi.org/10.4102/

ids.v49i1.1888

\section{Copyright:}

(C) 2015. The Authors

Licensee: AOSIS

OpenJournals. This work is

licensed under the Creative

Commons Attribution

License.
\end{abstract}

Read online:
Migration has been a fact of Judaeo-Christian life since the days when Abram left Ur of the Chaldeans to find God's promised land. It has become a far greater reality since the late 20th century, mainly as a result of wars, intranational conflicts, and natural disasters. As a result we have to deal with a larger number of internally or externally displaced persons (migrants) in Africa at the beginning of the 21st century than ever before. At the same time Africa reports on record numbers in terms of church growth. It is therefore clear that migration and Christian mission to migrants are serious items on the agenda of Christian mission in Africa. The article argues that migration is largely a result of a growing phenomenon of dehumanisation in Africa and worldwide: people tend to regard other people no longer as fellow human beings, created in the image of God. For this reason a very important missionary responsibility is to promote humanisation according to the gospel proclaimed by the new human being, Jesus of Nazareth. This calls for human development of migrants as well as indigenous Christians. It is my contention that the Christian community in Africa has not yet grasped this missionary vocation as it should have. Therefore, the article argues that Christian mission in Africa faces the task of humanising relationships between indigenous Christians and other migrants, and that this can be done through a well-developed programme of human development in which both migrants and indigenous Christians should participate.

Sending, migrasie en menslike ontwikkeling: 'n Nuwe benadering. Migrasie is ' $n$ realiteit van die Judese-Christelike lewe sedert Abram Ur van die Galdeërs verlaat het om God se beloofde land te vind. Dit het egter 'n groter realiteit geword sedert die laat twintigste eeu hoofsaaklik as gevolg van oorloë, intranasionale konflik en natuurrampe. As gevolg hiervan moes daar na 'n groter getal migrante in Afrika omgesien word aan die begin van die eenen-twintigste eeu as ooit tevore. In dieselfde periode het die kerk in Afrika met rekordgetalle gegroei. Dit behoort duidelik te wees dat migrasie en Christensending aan migrante hoog op die agenda van Christensending in Afrika behoort te wees. Hierdie artikel spruit voort uit die veronderstelling dat migrasie hoofsaaklik die gevolg van die groeiende verskynsel van verontmensliking (dehumanisering) in Afrika en wêreldwyd is, naamlik om ander mense nie as die beeld van God te erken nie. Om hierdie rede is dit die verantwoordelikheid van sending om menslike ontwikkeling aan die hand van die evangelie, soos dit deur die nuwe mens, Jesus van Nasaret verkondig is, te bevorder. Dit is ' $n$ roeping wat geldend is ten opsigte van migrante sowel as plaaslike Christene. Hierdie artikel veronderstel dat die Christelike gemeenskap nog nie hierdie sendingroeping na behore verstaan nie en sien die taak van sending in Afrika daarom as die vermensliking (humanisering) van die verhouding tussen plaaslike Christene en ander migrante. Hierdie doel kan verwesenlik word deur 'n behoorlik ontwikkelde program van menslike ontwikkeling waarin sowel migrante as Christene moet deel hê.

\section{Introduction}

Migration has been a fact of Judeo-Christian life since the days when Abram left Ur of the Chaldeans to find God's promised land. It has become a far greater reality since the late 20th century, mainly as a result of wars, international and intranational conflicts, and natural disasters. As a result we have to deal with a larger number of internally or externally displaced persons (migrants) in Africa at the beginning of the 21st century than ever before. At the same time Africa reports record numbers in terms of church growth. It is therefore clear that migration and Christian mission to migrants are serious items on the agenda of Christian mission in Africa. We argue that migration is largely a result of a number of phenomena. Two important ones are the growing gap between rich and poor (measured in terms of the so-called Gini-coefficient) and growing dehumanisation of people in Africa and worldwide. People increasingly tend to regard other people no longer as fellow human beings, created in the image of God, but rather as have-nots 
who invade their (the haves') space to survive in a parasitic way on wealth and prosperity for which they worked hard, whilst the others were too lazy to provide for themselves. We regard this situation as a very important missionary responsibility for the Christian community, to promote humanisation according to the gospel proclaimed by the new human being, Jesus of Nazareth. This calls for human development of migrants as well as indigenous Christians. It is our contention that the Christian community in Africa and elsewhere has not yet grasped this missionary vocation as it should have. Since we are Africans, we focus our attention more on the task in Africa, a task of humanising relationships between indigenous Christians and other migrants. This can be done, amongst others through a well-developed programme of human development in which both migrants as well as indigenous Christians should participate.

\section{Mission and development: A brief exposition}

One can argue that there has always been a developmental dimension to mission. This is so, amongst others, for three reasons. Firstly, mission aims at ensuring that the human being is fit for every good work (2 Tm 3:16-17) - an aim which is developmental in essence. In the second place, from its earliest beginnings in history mission included healing and educational dimensions, without which no development can take place. And finally, mission harbours an unquenchable eschatological dimension, waiting for and working towards a new heaven and a new earth. Our understanding of the radical (that which goes to the roots) link between mission and development is therefore not based in the first place in the historical link between mission and development during the colonial era, important though that might have been. It is especially the third of these reasons I wish to emphasise in this brief exposition, because, as Bosch (1991:501-502) perceptively remarked especially since the second half of the 20th century 'the eschatological office has been reopened'. I agree with Bosch that this new emphasis on eschatology is 'far from uniform' (1991:502), and base our position especially on aspects of the salvation-historical understanding of eschatology which takes history quite seriously. A hermeneutical key to grasping this approach is, according to Bosch (1991:503) the idea of the reign (kingdom) of God. This reign of God has already begun, but is also still coming every day - so we are still living, as it were, in an 'interim period'. As I understand it, God's chosen instrument to make his kingdom come every day during this period between Christ's first and second comings, is mission (1991:503). Such an understanding implies that it is impossible for Christian mission to ignore or neglect the historical world around us. To paraphrase the old Pietist saying: whoever knows that one day Christ will wipe away all tears, cannot leave the evil circumstances which cause these tears (hunger, sickness, illiteracy) to continue causing misery now. And whoever knows that one day God will heal all illnesses cannot leave any illness unattended to now. If one accepts this unbreakable link between eschatology and mission, therefore, Christian mission can in our understanding not evade its developmental responsibility. This responsibility accompanies also our mission to migrants - such a huge fact of missionary life today (cf. Ng'ang'a 2010:20). This provides the basis for my point of departure in this article.

\section{Some thoughts on anthropology: Our understanding of being human}

We use Archbishop Tutu's description of African understanding of humanity as a general guide to African ${ }^{1}$ anthropology (as given in an open discussion in 1987):

Africans believe in something that is difficult to render in English. We call it Ubuntu [Nguni languages], botho [SothoTswana]. It means the essence of being human. You know when it is there and when it is absent. It speaks about humaneness, gentleness, hospitality, putting yourself out on behalf of others, being vulnerable. It embraces compassion and toughness. It recognises that humanity is bound up in you, for we can only be human together. (p. 71)

Tutu's point of view confirms Setiloane's understanding (as given in an open discussion in 1975) that human beings are considered to be truly human by the way they care for others and accept anybody and everybody to care for and love. Both these points of view emphasise the importance of a communal and corporate understanding of humanity in Africa; one can indeed say that 'if one is not able to care for others then one is considered inhuman' (Ng'ang'a 2010:55). We would like to expand this understanding by pointing out that we find the deepest ground for this corporate humanity with the inbuilt obligation to care for others in the reality that human beings recognise in other human beings the image of God, in whose image we have all been created.

$\mathrm{Ng}^{\prime}$ anga's research was aimed at establishing the extent to which migrants' understanding of human beings had been influenced by what they experienced as a result of the xenophobic violence. It is important to point out straightaway that experiences differed: some migrants had very negative experiences throughout, before and after the events, whilst some had positive experiences especially in the period immediately after the violent outburst. One respondent (quoted in Ng'ang'a 2010) indeed interpreted personal positive experiences in the way South Africans helped them after the worst outbreaks precisely as a confirmation of the reality that all human beings were created in God's image:

God's people have good hearts, they have understanding that we are all created in the image of God and therefore we are all one in God. It is good to continue praying for the country and for these people that God can use them to change those with a bad spirit. (p. 58)

\footnotetext{
1.We are very aware of the reality that one cannot truly speak about Africa in the singular. Africa consists of many peoples in many contexts, so actually one can only singular. Africa consists of many peoples in many contexts, so actually one can only
speak about a 'plurality of Africas'. At the same time, though, there are certain very speak about a 'plurality of Africas'. At the same time, though, there are certain very
important commonalities in African life and thinking which allows one in some instances to refer to 'an African' understanding as a very general guideline.
} 
There was far more evidence of very negative experiences with indigenous South Africans, however. ${ }^{2}$ The negativity revealed itself already before the outbreak of public violence in May 2008. One respondent (in Ng'ang'a 2010:48) indeed remarked that: 'The people [South Africans] hate foreigners and I could not understand their language [but] I noted their hatred for us who are from outside'. ${ }^{3}$ Migrants often had negative experiences, for example when they had to go and look for medical assistance at state hospitals and clinics. We consider the aspect that migrants could be treated so negatively when seeking medical assistance ${ }^{4}$ as such an important indicator of the attitudes which reigned, that we wish to quote extensively one respondent's story ( $\mathrm{Ng}^{\prime}$ ang'a 2010):

When I became pregnant I went to the clinic and there they made me suffer so much saying that I do not qualify to get treatment, asking me for proof of residence, they said that the green card showed I was a foreigner. They made me feel that I do not deserve to be treated just because I am a foreigner. On another occasion a cockroach entered my ear at night and it was so painful that I had to go early to the clinic just to be treated, in a rude way when the doctor asked me where I came from. I told him that I am from Burundi and he just pointed at a map on the wall telling me that my country does not appear among the countries to be helped. Since I was in pain I tried to beg him to treat me since the cockroach was so disturbing in my ear but he made it clear that I was fighting a lost battle. I had to go and get some money and come back for them to remove the cockroach [by bribing the doctor]. (pp. 36-37)

As stated before, this was a qualitative and not quantitative analysis, so we cannot quantify our findings in this regard. What is quite clear to us, though, based on the totality of the findings, is that migrants had more negative than positive experiences in their human encounters before, during, and after the violent outbreaks.

Our understanding of a truly human existence is described more fully elsewhere (Saayman 2007:138-39). It is based on an understanding of our life as Christians in the world as 'an ongoing journey, with its goal to become an ordinary human person [as intended when God created us in his image]' (2007:138). We also understand our mission as a spiritual journey in which we grow into a deeper understanding of God self and his intention for the world. Becoming fully human for us is therefore not to be regarded as some sort of anti-climax, falling short of God's wish for us to grow spiritually; it is rather 'the climax of our spiritual-andmissionary journey' (2007:138). Our argument here is firmly based on New Testament evidence, such as Paul's prayer for the Ephesians (Eph 4:11-14). Here he states that he would regard the 'growing up' and 'becoming mature people' of the

2.The reactions reported by migrants are presented fully in Ng'ang'a (2010:26-47) A preliminary analysis of the findings is also presented in Ng'ang'a (2010:48-52).

3.In multilingual South Africa a common word was devised to refer to migrants, namely amakwerekwere: a word which has negative connotations which can indeed be compared (but not equated) to the negative meaning of the hate language term, kaffir, for black South Africans.
.

4.The South African Constitution and Bill of Rights guarantee access to state services also to refuges, asylum seekers and migrants. congregation as the climax of his work amongst them. Prové (2004:197-98) says of such people as Paul have in mind here, that they:

have love freely flowing in, through and out of them, whatever the situation. They are at ease daily with life and with all that belongs to the human condition, and are present to those in need ... They have 'become human' and they live 'Life'. (pp. 197-198)

This true essence of being a full, mature human being, can be found only in becoming one in the Spirit with the only true human being, Jesus of Nazareth (cf. Saayman 2007:139).

Since we consider this achievement of being fully human the result of a spiritual and missionary journey, it is obvious that nobody is born in this state. It requires a longer or shorter journey into God and into life with other human beings. We can state this also by saying: we require human and spiritual development, and we regard it as an integral dimension of our missionary journey (cf. Alawode \& Saayman 2013). We find the theological basis for our argument in Paul's charge to Timothy (2 Tm 3:16-17). It is significant that Paul uses the word anthropos here, referring to all human beings and not only the male of the species. So it is human beings, all of them, who require this dimension of human development in order that they might become full human beings, equipped for every good work.

Having argued the link between Christian mission and human development, let's now turn our attention to the issue of migrants and how mission as development can improve their precarious situation in nearly all the places they find refuge. The main aim is empowering them to become proud and self-sufficient human beings wherever they may find themselves. The main thesis in this article is that Christian mission should move away from the present response mainly to the alleviation of the results of human tragedy which generally accompanies forced migration. The human needs are generally so overwhelmingly obvious that the standard response is in the area of charity only. We do not wish to devalue these huge and obvious needs, but wish to argue that Christian mission should always look for a more holistic missional response. In our opinion this should mean becoming involved in the age-old symbiosis between mission and development. Only in this way can oppressed and suffering human beings be empowered to become mature human beings, equipped for every good work. It is to this topic that we now turn our attention.

\section{Multiple lenses on the definition of development}

Development is a complex issue. It refers to a complex world of institutions and ideas, one that is in flux, representing widely different approaches that can be reflected upon using multiple lenses. Thus, development or lack of it also manifests itself in different dimensions - dimensions that also need various lenses for the relevant assessment of development needs of the migrants. As a rule the migrants are always poor. Our intention here is to find the appropriate lens in order to 
establish what the development needs of the poor migrants are. According to Burkey (1993:35-39), development needs can be divided into at least four subdivisions, namely, human (personal), economic, political and social development needs.

\section{Human (personal) development}

Human (personal) development is a process by which individuals develop self-respect, and become more selfconfident, self-reliant, cooperative and tolerant of others through becoming aware of their shortcomings, as well as their potential for positive change Burkey (1993). This takes place through working with others, acquiring new skills and knowledge, and through active participation in the economic, social and political development of the community.

This shows that development in any meaningful sense must begin with and within the individual within everyone's specific context. Unless motivation comes from within, efforts to promote change will not be sustainable - the individual will remain under the power of others. Oyedepo (2005:7), one of the famous pastors in Nigeria, says 'Until something changes within you, nothing changes around you. Every change begins from within. Without a change within, there can never be a change without'.' Henry Wadsworth Longfellow (2015) also says 'All things must change to something new, to something different.'

\section{Economic development}

Economic development is a process by which people through their individual or joint efforts boost production for consumption and have a surplus to sell for cash. This means that the returns to the activity must be greater than the cost, that is, the activity must be profitable. The flipside of production is marketing or selling - there can be no cash profits without available markets. Therefore economic development also includes developing markets. It also means that some of the surplus produced must be reinvested in the same activity or in profitable new activities (Nolan 1998:27).

\section{Political development}

Swart (2003:405) says political development is a process of gradual change over time in which the people increase their awareness of their own capabilities, their rights and their responsibilities and use this knowledge to organise themselves so as to acquire political power in order to do the following:

- Participate in decision making at local level and to choose their own leaders and representatives at higher levels of government who are accountable to the people.

- Plan and share power democratically.

- Create and allocate communal resources evenly and efficiently amongst individual groups. Hence it may be possible to avoid corruption and exploitation, realise social and economic development and political stability and create a politicised population within the context of their own culture and their political system.

\section{Social development}

Social development is a process of gradual change in which people increase the awareness of their communal capabilities and common interests, and use this knowledge to analyse their needs; find solutions; organise themselves for cooperative efforts; and mobilise their human, financial and natural resources to improve, establish and maintain their social services and institutions within the context of their own culture and their own political system (Burkey 1993:39).

One can say that from a Christian perspective, the aim of holistic development (social, economic, political, etc.) should be to form human beings 'who understand and appreciate their integral role in society as both Christians, good and responsible citizens' (Kaulema 2010:76), in line with their Christian vocation to promote gospel values. All of these lenses will therefore be necessary in searching for a suitable kind of development which can be utilised by Christian mission to help alleviate poverty amongst the migrants. We therefore turn our attention to theories of development which could be very important for the migrants.

\section{Development}

In our understanding, development is not only an ambiguous concept but also one that has become discredited and unpopular amongst communities on the receiving end of the so-called development work. This happened because the history of the concept is closely associated with western ideas of modernisation, technological advancement and liberal and free-market economic ideologies. This proved that such an understanding of development is not good enough. It propagated colonisation and the disempowerment of the Third World countries by those of the First World. It failed to improve the economic, social and political lives of the poor in Third World countries. To some people in the West development aid became a tool for extending the dominance of western culture; to some people in Africa, it became an easy source of corrupt self-enrichment. To solve this problem we need to understand development as a comprehensive social process that includes the interdependence of economic, social, political and cultural factors, both nationally and internationally (Van Schakwyk 1996:48). This understanding of development implies a challenge to the status quo and breaking down of oppressive structures, thus changing the perspective of development to that of liberation. According to Van Schalkwyk (1996:48), the breaking down of negative structures is not enough for development. Once oppressive structures have been broken down by the liberating process of development, there is a need to build up a new society, and this process is called 'social transformation'. Anne Hope in her own view says during an open discussion:

social transformation implies building up a new society with an entirely different set of values as well as alternative economic, political, legal and educational structures which will create a just and equitable order.

Let us therefore look more closely at theories of development. 


\section{Theories of development}

The field of development in its broadest sense includes both socio-cultural and socio-economic aspects. Bullon (2007:93) argues that the classical discourse on development as promoting the welfare in poor regions, countries or localities had its origins in the western countries during the late 1940s and was institutionalised in the 1950s and 1960s. This discourse on development included security issues in the context of the Cold War, and viewed global poverty as a threat to the liberal world order. For this reason an interdisciplinary field of studies emerged, containing a set of theoretical cores with development economics as the leading discipline of the group. Bullon further states that the most important theoretical schools on the hermeneutics of development until the 1980s have been the following six development theories.

\section{Alternative development theory}

The alternative development school of thought tries to emphasise some features which have appeared across history in successful civilisations, as counterpoints to the modernist view. They suggest development should arise from within the context and be need-oriented, self-reliant, and ecologically sound and based on structural transformation. These emphases were proposed to improve the real conditions of poor people (migrants) who usually were excluded in the mainstream discourse (Bullon 2007:93).

\section{Dependency development theory}

From the late 1960s modernisation theory was confronted by the Latin American Dependencia School (a neo-Marxist interpretation), which, together with the more global world system theory, articulated the weak structural position of Third World countries in the world system against First World countries (Schuurman 2001:5). Since these countries occupied such a weak position, characterised by dominance of First World countries and dependency in Third World countries, they stated that development as it had been practiced since the Second World War would never solve the problem. The 'dependentists' therefore asked for more radical transformation, that is a liberation in theological terms, emphasising more autonomy by delinking their economies from the world market totally dominated by the First World (2001:7; cf. also Alawode \& Saayman 2013).

\section{Globalisation development theory}

In order to properly understand development in the new millennium, one needs to have a better understanding of the new concepts, ideas and debates surrounding the debate about globalisation (Stewart 2001:74). Modern technology, for example the Internet, satellite TV and communication technologies like cellular phones, contributes much to the notion of a global society. However, at the same time there are millions of less fortunate people who still live their lives totally untouched by these changes, and quite possibly will never be impacted by them in terms of their poverty. Globalisation is a concept used to describe new features of the international economy involving the emergence of global production systems, worldwide communication networks and the relatively free flow of finance over most of the world. Globalisation is also used to refer to new processes in politics, society and culture, which reflect increased international influence and interdependence. All the same, globalisation, the gigantic idea of the late 20th century, lacks precise definition. It is in danger of becoming, if it has not already become, the chestnut of our times (Held et al. 1999:7). Nonetheless, the term captures elements of a widespread perception that there is a broadening, deepening and speeding up of worldwide interconnections in all aspects of life, which must direct a new form of development.

\section{Modernisation development theory}

In the modernisation theory, a lack of development was defined in terms of the differences between rich and poor nations as understood in 'modern' (post 19th century) terms. Development in order to modernise in this case implied the bridging of the gap by the less developed countries. They were required to imitate and gradually assume the qualities of the modernised states, namely state-led investment, electronic technology and education were critical factors (Bullon 2007:93).

\section{Sustainable development theory}

This is affecting every contemporary policy and understood as the way to fulfil present human needs without exhausting the earth's finite resources, thus endangering the lives and opportunities of future generations (Bullon 2007:94). Quaddus (2004:115) define sustainable development as a process of development which meets the needs of the present without compromising the ability to meet those of the future. But according to Elliott (2006:9), sustainable development should also be understood as literally referring to maintaining development over time. She further argues that sustainable development is fundamentally about reconciling development and the environmental resources on which society depends (2006:46). Van Rooyen (2002:136-137) states that during 1992 in Rio de Janeiro, as part of the United Nations conference on Environment and Development, an action plan and blueprint for sustainable development was adopted by more than 178 governments. These governments committed their nations to take action to facilitate sustainable development and environmental preservation. The action plan was called Agenda 21. Agenda 21 proposes a plan for environmental management and development which provides for a new and integrated policy framework for national and regional action to enhance sustainable development. Agenda 21 includes strategies for good governance, democracy, human rights and an improved quality of life for the current generation and those to come. One cannot say that it has been successfully implemented yet.

\section{Transformation development theory}

Amongst mainly Evangelicals at Wheaton in 1983 (cf. Bosch 1991:406-408), a new term and concept of development emerged, namely transformative development, to be understood by Evangelicals as a holistic perspective of development (Bullon 2007:96). It is now recognised that Social Sciences 
and related disciplines help us understand what is at stake when we talk of 'social transformation' and its connectedness with holistic spirituality. Christian development will seek integration at every level. Theorists and practitioners need to understand and recognise that development involves the permanent and existential or continuous relationships between and amongst human beings and with our natural and social environment. In the same vein, it is important to remember that implicit in the idea of development is the division that is made between communities, societies or nations that are considered as the most advanced and those which are considered to have not yet undergone the necessary transformation towards prosperity and economic growth. Walt W. Rostow in Bragg (1987:23, 48) saw the process of development as a succession of natural stages from traditional to modern, in which societies develop from a backward stage through the transformational process until the take-off into sustained economic growth. This process accelerates, according to the theory, through the transfer of knowledge, technology, and capital from the advanced to the less advanced nation, until it reaches the final stages of high production and mass consumption (August 2006:2). Modernisation as a development construct has ignored indigenous culture within its paradigm of sustained economic growth. August observes that the dominant (western) monoculture of modernisation has led to the developing world or the 'underdeveloped world' being continually dependent. The have-nots depend on the haves instead of being interdependent (Swart 2010:411-3).In view of the above, August (2006) makes an acute observation that theology values development as long as it is holistic and peoplecentred, reflects respect for human dignity and self-worth'. However, the relationship between culture and theology will always exhibit a dialectical tension. August argues for an epistemology of transformation as a Christian framework for looking at human and social change. His (August) hypothesis is that the best characteristic of the Transformational development theory is its sense of hospitality - in that it is a theology of generosity which requires a willingness to embrace others. We believe this is an emancipatory process that should be supported in church and society as it emphasises non-discriminative cultural reciprocity based on equality and respect for the dignity of all human beings. Whereas many development workers from the West always think of development as 'a programme prepared for implementation among the poor', they have often forgotten that the poor are also human beings with their own thinking abilities and understanding of what they need. Our plea is therefore for transformative development plans to be instituted in active dialogue and cooperation with the community involved they generally have clear and workable ideas about what kinds of development programmes will benefit them. Mission praxis for development should also be considered.

\section{Mission praxis for development}

Migration is a key feature of our changing world, and one that brings exciting new opportunities and challenges. Praxis is deeply concerned about the increasing vulnerability of migrants and their families - a consequence of the circumstances which cause them to leave their country, the bureaucracy of the immigration process, and the difficulties of settling down in the new country. Furthermore, migration within developing countries is an important yet often ignored phenomenon, producing opportunities and challenges similar to international migration.

With the migrants in focus, we believe that deep within our heart is a passion to see God's kingdom extended. We can talk with great fervour about the mission and even execute wonderful marketing schemes that boldly declare our message, but still lose sight of the one element that is meant to drive the mission - the LOVE for God which results in LOVE for people. God is looking for a people whose eyes are wet, who have hearts that are broken and knees that are bent.

The main purpose of mission praxis for the development of migrants is to reorient leaders around the world to what we call the 'irreducible core' of Christianity, namely:

- $\quad$ Loving God (Mt 22:37-38).

- Loving others as yourself (Mt 22:39).

- Making disciples as you go (Mt 28:19).

Jesus made it clear with the two great relationships - we are to love God with all of our hearts and love our neighbours as ourselves. From these two great relationships we find the great commandment which tells us that as we go, we must make disciples of all nations. From the great commandment the Bible makes it clear that we are to do this together as the great community (Ac 2:42-47). The 'irreducible core' makes it quite clear that the mission is a relational enterprise that flows naturally from one's relationship with God, resulting in love for others, the formation of community, and love that drives the community to 'making disciples' as a way of life.

\section{Recommendations}

- In the spirit of partnership, there should be an external migration policy that is balanced and comprehensive. It is the world's leading donor of development assistance and it will continue to provide substantial support in the years to come. We must stand ready to share our experiences with interested countries and organisations in order to better the lot of migrants.

- There should be a clarion call to all the relevant agencies and international organisations in the field of migration and development to pursue a more coherent, comprehensive and better coordinated approach at global level. It is necessary to enable the global community to capitalise on opportunities and to tackle the challenges associated with international migration. In today's globalised world, all countries face similar challenges in relation to migration and development. Yet countries will approach the situation in different ways, since their priorities, size, demographic and economic characteristics vary. International cooperation is therefore necessary to ensure that people moving in search of a better life are able to exercise their rights in a safe environment. 
- I am using this medium to call on development policy makers and practitioners to step up their engagement in strengthening the development-migration link, both by better integrating migration and mobility issues in development programming and through stronger participation in relevant international fora. The development processes rely on mobility, which is necessary to ensure efficient labour matching and facilitates transfers of social, financial and human capital. Development also fosters mobility, providing greater resources for people to migrate in search of opportunities. A number of processes will further drive mobility in the future, including global wealth shifts, regional and global economic integration and environmental degradation related to climate change. If it is to be fit for the 21st century, development thinking must therefore fully integrate the role of migration and mobility as development enablers, and recognise the essential role of effective migration governance in limiting the potential negative impacts of migration on development.

- Finally, I call on migration policy makers and practitioners to take full account of development concerns in migration policy and step up their responsibility in ensuring respect for and protection of the human rights of all migrants through all dimensions of migration governance. Migration and mobility is about freedom. It is about giving each and every individual the opportunity and the ability to influence their life situation, economically and socially. The impact of respecting human rights goes far beyond the individual migrant, as it also benefits both the home society and the society in which migrants live and work. Empowering individuals to accede their rights is a winning strategy, both for effective migration governance and for sustainable development.

\section{Conclusion}

The tragedy of many western development programmes in which even the western churches have participated, is their treatment of people as 'objects for compassionate hand-outs' rather than subjects with whom they can work together in synergy to achieve their own destiny. Moreover, August (2006:2-4) observes that human beings are multidimensional with the psychological need for dignity, self-esteem, freedom, and participation. To reduce them to mere producers and consumers is to assume that some basic materialism is the goal of life. Of course, meeting human material needs makes life possible, but as Maslow's hierarchy of needs shows, it is not sufficient for human self-realisation and actualisation. The loss of traditional values and whole cultures through the cultural imperialism of westernisation is increasing. Modernisation has provided a radical improvement for onefourth of the world's population, but is complex. However, we will not fail to point out that though development necessarily involves structural transformation, which implies political, social and economic transformation, primarily, development should start from where the people are. Rather than just handing out food to people, our task then is to engage in a process with them to discover the hidden talents and resources that can help them truly realise their full humanity in a sustainable way. This is what the church is supposed to do in line with her calling as agent of the missio Dei.

\section{Acknowledgements}

I wish to express my gratitude to the Lord Almighty for his grace upon my life, and my host professor at the North-West University, Mafikeng, Professor Alfred Brunsdon for being there for me always.

\section{Competing interests}

The author declares that he has no financial or personal relationship(s) that may have inappropriately influenced him in writing this article.

\section{References}

Alawode, A.O. \& Saayman, W.A., 2013, 'Back to the future: Thoughts about development and the future of Missiology', Unpublished paper.

August, K.T., 2006, 'The nature of interculturality in development: A theological perspective of relationality', Unpublished paper, University of Stellenbosch, Stellenbosch.

Bosch D.J., 1991, Transforming mission: Paradigm shifts in theology of mission, Orbis Books, Maryknoll, NY.

Bragg, W.G., 1987, 'From development to transformation', in V. Samuel \& C. Sugden (eds.), The church in response to human need, pp. 23-25, 48-61, Eerdmans, Grand Rapids, MI.
(eds.), The

Bullon, H.F., 2007, 'Secular and technical perspectives on development: A brief history', in R.K. Corrie et al. (eds.), Dictionary of mission theology: Evangelical foundation, pp. 93-96, InterVarsity, London.

Burkey, S., 1993, People first: A guide to self-reliant participatory rural development, Zed Books, London.

Elliott, J.A., 2006, An introduction to sustainable development, 3rd edn., Routledge, London.

Held, D., McGrew, A., Goldblatt, D. \& Perraton, J., 1999, Global transformations politics, economies and culture, Polity, Cambridge, MA.

Kaulema, D., 2010, Political participation in Zimbabwe, African Forum for Social Teachings (AFCAST), Harare.

Longfellow, H.W., 2015, 'The changeless face of change', viewed 24 March 2015, from http://www.healpastlives.com/pastlf/quote/quchange.htm.

Ng'ang'a, S.W., 2010, 'Aspects of migrants' theology of God and of human beings: A missiological exploration of some responses to the xenophobic violence in and around Tshwane, May 2008', Unpublished MTh dissertation, Faculty of Theology, Unisa, Pretoria.

Nolan, A., 1998, 'In the end, what can churches do about poverty?', Challenge 50, $26-27$.

Oyedepo, D.O., 2005, Towards empowerment for change, Dominion Publishing House, Lagos.

Prové, G., 2004, Becoming human: A story of transformation through conflict and healing, Eburon, Delft.

Quaddus, M.A. (ed.), 2004, Handbook of sustainable development planning: Studies in modelling and decision support, Edward Elgar Publishing, Cheltenham. http:// dx.doi.org/10.4337/9781845423544

Saayman, W.A., 2007, Being missionary being human: An overview of Dutch Reformed mission, Cluster Publication, Pietermaritzburg.

Schuurman, F.J., 2001, Globalization and development studies: Challenges for the 21st century, Sage, London.

Stewart, P., 2001, Development and administration - Theories, Unisa, Pretoria. (DVA201-T).

Swart, I. (ed.), 2010, Religion and social development in post-apartheid South Africa, Sun Press, Stellenbosch.

Van Rooyen, E.V., 2002, 'Sustainable development and environmental management in developing countries', in J.O. Kuye (ed.), Critical perspectives on public administration: Issues for consideration, pp. 24-25, Heinemann, Cape Town.

Van Schalkwyk, A., 1996, 'The church, community development and liberation', Missionalia 24(9), 40-62. 